\title{
Characteristics of Households and Indigenous Chicken Consumption in N'Djamena (Chad)
}

\author{
Issa Youssouf Adoum ${ }^{1,}$, , Mopate Logtene Youssouf ${ }^{2}$, Vounparet Zeuh ${ }^{3}$, Ayssiwede Simplice Bosco ${ }^{4}$, \\ Bada Algom Oumar ${ }^{1}$, Adam Bakhit Mustapha ${ }^{1}$, Ardjoun Khalil Djalal ${ }^{1}$, Missohou Ayao ${ }^{4}$ \\ ${ }^{1}$ National High Institute of Sciences and Techniques, Abeche (INSTA) Ex University Institute of Sciences and Techniques, Abeche, Chad \\ ${ }^{2}$ Livestock Research Institute for Development (LRID) Ex Zootechnical and Veterinary Research Laboratory, N'Djamena, Chad \\ ${ }^{3}$ Livestock Polytechnic Institute of Moussoro, Moussoro, Chad \\ ${ }^{4}$ Inter-State School of Sciences and Veterinary Medicine, service of Animal Husbandry Food Sciences (EISMV), Dakar-Fann, Sénégal
}

\section{Email address:}

issayou@gmail.com (I. Y. Adoum), mopate.ly@gmail.com (Mopate L. Y.), vounzeuh@yahoo.fr (V. Zeuh), ayissimbos@yahoo.fr(A. S. Bosco),oumar_algo@yahoo.fr(B. A. Oumar),bakhitmusta@yahoo.fr (A. B. Mustapha), djalalardjoun@yahoo.fr(A.K. Djalal),missohou@refer.sn (M. Ayao)

\section{To cite this article:}

Issa Youssouf Adoum, Mopate Logtene Youssouf, Vounparet Zeuh, Ayssiwede Simplice Bosco, Bada Algom Oumar, Adam Bakhit Mustapha, Ardjoun Khalil Djalal, Missohou Ayao. Characteristics of Households and Indigenous Chicken Consumption in N'Djamena (Chad). Animal and Veterinary Sciences. Vol. 3, No. 4, 2015, pp. 106-112. doi: 10.11648/j.avs.20150304.12

\begin{abstract}
The objective of the study was to analyze the home consumption of local chickens in N'Djamena. It was conducted using a crosscutting and retrospective survey of a purposive sample per a quota of 250 households in 10 districts of the city. The heads of household surveyed are in average $41.5 \pm 9.4$ years old and led families made up of $9.6 \pm 4.9$ persons. The majority of respondents (94.4\%) were married and educated (78.8\%) at different levels. Employees were the majority (68\%). The majority of households (62\%) had an average monthly income ranging from less than 50,000 F CFA to 150,000 F CFA and about $82 \%$ of households spend in average 25,000 to $75,000 \mathrm{~F} \mathrm{CFA}$ for food per month. Indigenous chicken is consumed during parties (32.3\%), Christian festivals (38.0\%) and visits by VIPs $(39.7 \%)$. Most respondents $(71 \%)$ had a monthly consumption frequency ranging from 2 times $(45.6 \%)$ or 3 times $(25.2 \%)$. Households headed by women consumed an average 2.01 chickens as against 1.78 heads for households led by men $(\mathrm{p}>0.05)$. All respondents $(100 \%)$ stated having a preference for indigenous chicken. Taste and price are considered as the main determinants of indigenous chicken consumption in households in N'Djamena.
\end{abstract}

Keywords: Consumption, Indigenous Chicken, Households, N'Djamena, Chad

\section{Introduction}

N'Djamena, the capital city of Chad, with its administrative, economic and political functions, has a population of 993,492 in 2009 , representing $41 \%$ of the urban population of Chad with a high annual growth rate of about $5 \%$ [14].

Urban concentration and city food supply problems are great development concerns in Africa [26]. The contribution of agricultural and pastoral productions in feeding city populations is undeniable [19]. African cities are safe outlets for agricultural products near and distant areas [7].

In Sub-Saharan Africa, over $80 \%$ of poultry livestocks are bred in family production systems. Family poultry plays an important role in the fight against poverty in rural areas and an irreplaceable socio-cultural role in African societies [8, $18,25,28,29]$. Thus poultry reared are intended for food but also for use in traditional rituals, guest receptions, gifts and used in the barter system $[1,8]$.

Given the population growth in developing societies and speculation on food prices, consumption of animal products is influenced by various socio-economic factors [21]. Predictions of demographic changes and growth of individual consumption of animal products show that, by 2020, there will be need to produce more than 100 billion tons of meat in developing countries to cope with demand [6].

Village livestock farming provides animal protein readily available to households. Indigenous chicken meat has an 
organoleptic quality especially appreciated by African consumers in sub-Saharan Africa [2, 16, 27].

In urban areas where consumer habits are changing rapidly, there is not enough information on chicken consumption patterns [27]. N'Djamena does not make exception to this rule and lack of data about local chicken consumption in households.

The objective of this study was to analyze the main determinants of local chicken consumption in households in N'Djamena.

\section{Materials and Methods}

\subsection{Study Framework}

The study was carried out between October and December 2010 in 10 districts of N'Djamena city. It focused on the characteristics of households and consumption of indigenous chickens that could be found there. As the Capital city of Chad, N'Djamena borders with Cameroon. Its population was estimated at about one million people in the last census in 2009 [14]. It extends between $12^{\circ}$ and $13^{\circ}$ North latitude and $15^{\circ}$ and $16^{\circ}$ East longitude.

\subsection{Data Sampling and Collection Methods}

The survey was conducted among a sample of 250 households. This survey is based on a purposive sampling and quota. The number of households to be surveyed in each district was proportional to the population size defined in the district in relation to the total population of the city of N'Djamena. It was conducted in two steps: a questionnaire validation pre-survey in a few households distributed in the different districts and a crosscutting and retrospective survey carried out among heads of households targeting people making family expenses. The information sought included:

- The location and socio-economic characteristics of households;

- The consuming practices of the major meat types, the different species of poultry consumed in their order of preference, the types of meat consumed depending on the circumstances. Moreover, the rank of the consumption frequency of chicken, the consumed quantity, the main dishes and the chicken supply method were analyzed.

- Purchasing practices and expenses on food per month in households, as well as criteria for buying chicken as well as quality attributes were collected.

- Socio-cultural practices of using chicken, including types of selected chickens, ritual sacrifices and offerings in households.

\subsection{Statistical Analyses}

The raw data were coded and entered into "Excel". Subsequently, these data were imported into SPSS [23] processing software. Descriptive statistical analysis (calculating frequencies, means and standard deviations, chitwo test) and analysis of variance (ANOVA) were performed.
The significance level adopted was $5 \%$.

\section{Results}

\subsection{Socio-Economic Characteristics of Households}

The heads of households $(\mathrm{HH})$ were in average 41.5 \pm 9.44 years old. Men, who were more in number, have an average age $(44.7$ years $)$ significantly higher $(\mathrm{p}<0.05)$ than that of women (33.2 years). Almost all were married with an average of $9.6 \pm 4.92$ people under their responsibility, of whom $1.3 \pm 0.6$ wives, $5.41 \pm 3.7$ children and $2.84 \pm 1.4$ active. The vast majority (about $79 \%$ ) of HHs was educated and over half (54\%) Islamized (Table I). They are mostly (59.5\%) employees (civil servants, police force and private employees) and the rest (40.5\%) was made up of traders, workers and others (Table I). Their wives practiced more household and commercial activities than salaried workers. Almost half (49\%) of households were indigenous of regions of Chari-Baguirmi and those close to the capital city, such as Mayo-Kebbi, Batha and Tandjile regions.

Table I. Socio-economic characteristics of household heads surveyed in N'Djamena (Chad).

\begin{tabular}{|c|c|c|c|}
\hline Parameter & Status & Number & Percentage $(\%)$ \\
\hline \multirow{2}{*}{ Gender } & - Women & 70 & 28 \\
\hline & - Men & 180 & 72 \\
\hline \multirow{3}{*}{ Religion } & - Christian & 109 & 43.8 \\
\hline & - Muslim & 135 & 54.2 \\
\hline & - Animist & 5 & 2.0 \\
\hline \multirow{7}{*}{$\begin{array}{l}\text { Region of } \\
\text { origin }\end{array}$} & - Chari-Baguirmi & 42 & 16.8 \\
\hline & - Mayo-Kebbi & 32 & 12.8 \\
\hline & - Batha & 25 & 10.0 \\
\hline & - Tandjile & 24 & 9.6 \\
\hline & - Guera & 22 & 8.8 \\
\hline & - East Logone & 16 & 6.4 \\
\hline & - Others & 89 & 35.6 \\
\hline \multirow{4}{*}{ Education } & - University & 48 & 19.2 \\
\hline & - Secondary & 83 & 33.2 \\
\hline & - Primary & 66 & 26.4 \\
\hline & - Illiterate & 53 & 21.2 \\
\hline \multirow{4}{*}{ Marital Status } & - Married & 236 & 94.4 \\
\hline & - Divorced & 7 & 2.8 \\
\hline & - Widow & 6 & 2.4 \\
\hline & - Single & 1 & 0.4 \\
\hline \multirow{6}{*}{$\begin{array}{l}\text { Activity of } \\
\text { the household } \\
\text { head }\end{array}$} & - Civil servant & 79 & 32.4 \\
\hline & - Trader & 43 & 17.6 \\
\hline & $\begin{array}{l}\text { - Private } \\
\text { emplovee }\end{array}$ & 36 & 14.8 \\
\hline & - Military & 30 & 12.3 \\
\hline & - Worker & 21 & 8.6 \\
\hline & - Other & 35 & 14.3 \\
\hline \multirow{4}{*}{$\begin{array}{l}\text { Activity of } \\
\text { wives }\end{array}$} & - Housewife & 116 & 48.1 \\
\hline & - Trader & 73 & 30.3 \\
\hline & $\begin{array}{l}\text { Private } \\
\text { Employee }\end{array}$ & 33 & 13.7 \\
\hline & - Other & 19 & 7.9 \\
\hline
\end{tabular}




\subsection{Monthly Income and Food-Related Expenses}

Households had an average monthly income ranging from 50,000 to $150,000 \mathrm{~F}$ CFA and those who spent between 25,000 and 75,000 FCFA were in the majority (Table II). Monthly expenses for food were significantly associated $(p<0.05)$ with household income.

Table II. Categories of income and monthly expenditure of households on food (in F CFA) and number of chickens consumed in N'Djamena (Chad).

\begin{tabular}{llll}
\hline Revenue & \multicolumn{3}{l}{ Expenditure } \\
\hline Category & Rate (\%) & Category & Rate (\%) \\
\hline $50,000-150,000$ & 62.0 & $25,000-75,000$ & 81.6 \\
$150,000-250,000$ & 33.6 & $75,000-150,000$ & 14.0 \\
Over 250,000 & 4.4 & Over 150,000 & 4.4 \\
\hline
\end{tabular}

In relation to income, monthly numbers of consumed chickens have varied. Households with incomes of more than 150,000 F CFA consumed three (03) chickens. Those with incomes between 100,000 and 150,000 F CFA have eaten two (02) fowls and those whose incomes were below 100,000 F CFA, one (01) chicken.

\subsection{Types of Poultry Consumed}

The indigenous chicken has ranked at the top of preferences of about $44 \%$ of household heads (Table III).

Table III. Types of poultry consumed by order of preference in households in the city of N'Djamena (Chad).

\begin{tabular}{llll}
\hline Species consumed & Number & Percentage (\%) \\
\hline - Indigenous Chicken & 109 & 43.6 \\
- Indigenous Chicken, Duck & 27 & 10.8 \\
- Indigenous Chicken, Pigeon & 16 & 6.4 \\
- Indigenous Chicken, Reform chicken & 13 & 5.2 \\
- Indigenous Chicken, Broiler & 13 & 5.2 \\
- Heterogeneous consumption (no & 72 & 28.8 \\
\hline
\end{tabular}

\subsection{Type of Meat Consumed Depending on Circumstances}

Meat from small ruminants was mostly consumed during religious (Muslim and Christian) festivals, children's baptisms, on New Year's Day and at weddings (Table IV). As for indigenous chicken meat, it was more consumed during parties and upon receiving a distinguished guest.

Table IV. Type of meat consumed depending on circumstances in households in the city of N'Djamena (Chad).

\begin{tabular}{ll|ll}
\hline Event & $\begin{array}{l}\text { Type of meat } \\
\text { consumed }\end{array}$ & Number & Percentage (\%) \\
\hline & SR, NC, fish & 31 & 12.5 \\
& Cattle, SR, NC, & 29 & 11.7 \\
& SP, fish & 21 & 8.5 \\
Ordinary Life & SR, NC, & 20 & 8.1 \\
$(\mathrm{n}=248)$ & Cattle, SR, NC, fish & 20 & 8.1 \\
& SR & 15 & 6.0 \\
& SR, fish & 15 & 6.0 \\
& Other & 97 & 30.1 \\
\hline
\end{tabular}

\begin{tabular}{|c|c|c|c|}
\hline Event & $\begin{array}{l}\text { Type of meat } \\
\text { consumed }\end{array}$ & Number & Percentage (\%) \\
\hline \multirow{4}{*}{ Week-end $(\mathrm{n}=76)$} & Fish & 31 & 40.8 \\
\hline & $\mathrm{NC}$ & 17 & 22.4 \\
\hline & $\mathrm{NC}$, fish & 16 & 23.9 \\
\hline & Other & 12 & 15.8 \\
\hline \multirow{6}{*}{$\begin{array}{l}\text { Party } \\
(\mathrm{n}=133)\end{array}$} & $\mathrm{NC}$ & 43 & 32.3 \\
\hline & SR & 29 & 21.8 \\
\hline & SR, fish & 17 & 12.8 \\
\hline & Fish & 16 & 12.0 \\
\hline & SR, NC, & 16 & 12.0 \\
\hline & Other & 12 & 9.00 \\
\hline \multirow{3}{*}{$\begin{array}{l}\text { Moslem Festival } \\
(\mathrm{n}=145)\end{array}$} & SR & 133 & 91.7 \\
\hline & Cattle, SR & 4 & 2.8 \\
\hline & Other & 8 & 5.5 \\
\hline \multirow{3}{*}{$\begin{array}{l}\text { Christian Festival } \\
(\mathrm{n}=50)\end{array}$} & SR & 25 & 50.0 \\
\hline & $\mathrm{NC}$ & 19 & 38.0 \\
\hline & Other & 6 & 12.0 \\
\hline \multirow{4}{*}{$\begin{array}{l}\text { New Year } \\
(n=99)\end{array}$} & SR & 52 & 52.5 \\
\hline & $\mathrm{NC}$ & 25 & 25.3 \\
\hline & SR, NC, & 7 & 7.1 \\
\hline & Other & 15 & 15.2 \\
\hline \multirow{4}{*}{$\begin{array}{l}\text { Baptism } \\
(\mathrm{n}=156)\end{array}$} & SR & 88 & 56.4 \\
\hline & Cattle, SR & 54 & 34.6 \\
\hline & Cattle & 11 & 7.1 \\
\hline & Other & 3 & 1.9 \\
\hline \multirow{4}{*}{$\begin{array}{l}\text { Wedding } \\
(\mathrm{n}=145)\end{array}$} & SR & 69 & 47.6 \\
\hline & Cattle, SR & 54 & 37.2 \\
\hline & Cattle & 19 & 13.1 \\
\hline & Other & & 2.1 \\
\hline \multirow{4}{*}{$\begin{array}{l}\text { Funeral } \\
(\mathrm{n}=147)\end{array}$} & Cattle, SR & 59 & 40.1 \\
\hline & SR & 58 & 39.5 \\
\hline & Cattle & 27 & 18.4 \\
\hline & Other & 3 & 2.0 \\
\hline \multirow{7}{*}{$\begin{array}{l}\text { Distinguished } \\
\text { guest } \\
(\mathrm{n}=224)\end{array}$} & $\mathrm{NC}$ & 89 & 39.7 \\
\hline & $\mathrm{NC}$, fish & 36 & 16.1 \\
\hline & Camel, pork & 31 & 13.8 \\
\hline & SR & 16 & 7.1 \\
\hline & SR, NC, camel, pig & 16 & 7.1 \\
\hline & $\mathrm{SR}, \mathrm{NC}$ & 15 & 6.7 \\
\hline & Other & 21 & 9.4 \\
\hline
\end{tabular}

$\mathrm{SR}=$ small ruminant; $\mathrm{NC}=$ indigenous chicken

\subsection{Supply, Criteria and Purchase Price, Consumption Frequencies and Cooking Modes}

The majority of households (60\%) got their supply from markets in N'Djamena focusing, for approximately $44 \%$ of them, on price and weight criteria for the purchase of chickens (Table V). The average price of broilers was higher than that of reform hens and indigenous chickens. The majority of households $(70.8 \%)$ have a consumption frequency of two to three chickens per month. The monthly average was $1.85 \pm 1.167$ heads, being about two chickens with a variation from 2.01 chickens for households headed by women to 1.78 in those led by men. The sauce is still the most popular practice of cooking in households $(26.0 \%)$ followed by soup (16.0\%). 
Table $\boldsymbol{V}$. Supply, criteria and purchase prices, consumption frequencies and cooking modes of indigenous chickens in households in the city of N'Djamena (Chad).

\begin{tabular}{|c|c|c|c|}
\hline Character & Status & Number & Percentage (\%) \\
\hline \multirow{5}{*}{ Supply mode } & N'Djamena Market & 149 & 59.6 \\
\hline & $\begin{array}{l}\text { N'Djamena Market, } \\
\text { village market }\end{array}$ & 39 & 15.6 \\
\hline & $\begin{array}{l}\text { N'Djamena Market, } \\
\text { own stock }\end{array}$ & 14 & 5.6 \\
\hline & Own stock & 10 & 4.0 \\
\hline & Other & 38 & 15.2 \\
\hline \multirow{4}{*}{$\begin{array}{l}\text { Rate of } \\
\text { consumption }\end{array}$} & 3 times/month & 63 & 25.2 \\
\hline & 2 times/month & 114 & 45.6 \\
\hline & Once/month & 56 & 22.4 \\
\hline & Other & 17 & 6.8 \\
\hline \multirow{6}{*}{ Cooking Mode } & Sauce & 65 & 26.0 \\
\hline & Soup & 40 & 16.0 \\
\hline & Sauce, soup & 28 & 11.2 \\
\hline & Sauce, fried chicken & 26 & 10.4 \\
\hline & Soup, fried chicken & 26 & 10.4 \\
\hline & Other & 65 & 26.0 \\
\hline \multirow{6}{*}{$\begin{array}{l}\text { Most important } \\
\text { purchase criteria } \\
(n=249)\end{array}$} & Price & 71 & 28.4 \\
\hline & Weight & 38 & 15.2 \\
\hline & Age, price & 38 & 15.2 \\
\hline & Age & 30 & 12.0 \\
\hline & Size & 18 & 7.2 \\
\hline & Other & 55 & 22.0 \\
\hline \multirow{4}{*}{\multicolumn{2}{|c|}{$\begin{array}{l}\text { Number of chickens consumed / month } \\
\text { Price of village chicken (in F CFA) } \\
\text { Price of Reform chicken (in F CFA) } \\
\text { Broiler prices(in F CFA) }\end{array}$}} & \multicolumn{2}{|c|}{$1.85 \pm 1.167$} \\
\hline & & \multicolumn{2}{|c|}{$2839 \pm 414.14$} \\
\hline & & \multicolumn{2}{|c|}{$4879 \pm 334.6$} \\
\hline & & \multicolumn{2}{|c|}{$5055 \pm 300.04$} \\
\hline
\end{tabular}

\subsection{Meat Type Classification According to Organoleptic Quality}

The main organoleptic qualities that motivated the consumption of chicken compared to other meats were the color of the skin, cooking easiness, tenderness, flavor and the natural character of the meat (Table VI).

Table VI. Classification of different meat types of meat in terms of indicators and quality attributes in households in the city of N'Djamena (Chad).

\begin{tabular}{llll}
\hline Quality attribute & $\begin{array}{l}\text { Type of meat } \\
\text { consumed }\end{array}$ & Number & $\begin{array}{l}\text { Percentage } \\
\text { (\%) }\end{array}$ \\
\hline $\begin{array}{l}\text { Color of the skin } \\
(\mathrm{n}=32)\end{array}$ & Poultry & 20 & 62.5 \\
& Fish & 12 & 37.5 \\
Cooking facility & Poultry & 85 & 75.9 \\
$(\mathrm{n}=112)$ & Fish & 25 & 22.3 \\
& Small ruminants & 2 & 1.8 \\
Tenderness (n=85) & Poultry & 80 & 94.1 \\
& Fish & 5 & 5.9 \\
Taste (n=174) & Poultry & 169 & 97.7 \\
& Fish & 4 & 2.3 \\
Hygienic quality & Poultry & 114 & 88.4 \\
$(\mathrm{n}=129)$ & Fish & 15 & 11.6 \\
\hline
\end{tabular}

\subsection{Criteria for Choosing the Indigenous Chickens}

All of the respondents stated that they had a preference for indigenous chicken. More than half $(55.6 \%)$ of them justified this preference by its most succulent taste, cheaper price compared to that of reform hens, broilers and other poultry, the natural character of its production and market availability
(Table VII).

Table VII. Determining factors for preferring indigenous chicken in households in N'Djamena (Chad).

\begin{tabular}{llll}
\hline Characters & Responses & Frequency & \% \\
\hline & Tastier, cheaper & 34 & 13.6 \\
& Tastier & 28 & 11.2 \\
& Tastier, more natural & 20 & 8.0 \\
& Tastier, more natural & 18 & 7.2 \\
Reason for & Cheaper & 15 & 6.0 \\
preference & Tastier, cheaper, more natural, & 14 & 5.6 \\
& Available on market & 10 & 4.0 \\
& Cheaper, preferring one's own & 111 & 44.4 \\
& Other & & \\
\hline
\end{tabular}

\subsection{Sociocultural Use of the Indigenous Chicken}

More than half (53\%) of respondents said they did not use the meat of indigenous chicken in ritual sacrifices as against $47 \%$ who made use of it (Table VIII). The chickens used for that purpose were mainly purchased on the market. The frequency of its use was occasional for over half (51.3\%) of people or annually (43.7\%). The purchase of chicken intended for sacrifice was essentially based on feather color $(66.7 \%)$, including white, red, multicolored and the male sex $(32.7 \%)$. As for the ritual practice, chicken is either simply bled $(48.6 \%)$ or cooked and distributed $(35.2 \%)$.

Table VIII. Use of indigenous chicken in ritual practices in the households surveyed in N'Djamena (Chad).

\begin{tabular}{|c|c|c|c|}
\hline Characters & Responses & Number & $(\%)$ \\
\hline \multirow{2}{*}{$\begin{array}{l}\text { Using indigenous } \\
\text { chicken for sacrifices }\end{array}$} & Yes & 117 & 46.8 \\
\hline & No & 133 & 53.2 \\
\hline \multirow{4}{*}{$\begin{array}{l}\text { Chicken Acquisition } \\
\text { Mode } \\
(n=156)\end{array}$} & Purchasing from market & 108 & 69.3 \\
\hline & Choosing from one's stock & 26 & 16.6 \\
\hline & Gift & 19 & 12.2 \\
\hline & Home delivery & 3 & 1.9 \\
\hline \multirow{3}{*}{$\begin{array}{l}\text { Frequency of use } \\
(n=119)\end{array}$} & Need-based & 61 & 51.3 \\
\hline & Annually & 52 & 43.7 \\
\hline & Other & 6 & 5.0 \\
\hline \multirow{3}{*}{$\begin{array}{l}\text { Criteria for } \\
\text { purchasing chicken } \\
\text { for sacrifice }(n=150)\end{array}$} & Feather colour & 100 & 66.7 \\
\hline & Sex & 49 & 32.7 \\
\hline & Other & 1 & 0.6 \\
\hline \multirow{3}{*}{$\begin{array}{l}\text { Practice of ritual } \\
\text { sacrifice using local } \\
\text { chicken }(n=142)\end{array}$} & Chicken is bled & 69 & 48.6 \\
\hline & $\begin{array}{l}\text { Chicken is cooked and } \\
\text { distributed }\end{array}$ & 50 & 35.2 \\
\hline & $\begin{array}{l}\text { Chicken is given to the } \\
\text { marabout }\end{array}$ & 23 & 16.2 \\
\hline
\end{tabular}

\section{Discussion}

This study establishes for the first time the relationship between the monthly frequency of indigenous chicken consumption and socio-economic characteristics of households in the city of N'Djamena. In addition, it has established the central spot occupied by the meat of local chicken among meats consumed at weekends and during a visit paid at home by a host or a distinguished guest. The same goes for its use in ritual ceremonies. These observations 
were similar to those made in Cameroon, where urban indigenous chicken consumption is linked to some particular circumstances (traditional ceremonies and religious celebrations) for which the other two types of chicken available on the market (broilers and imported cuts) are not suitable [13]. In Sub-Saharan Africa, the various events and religious celebrations significantly affect the consumption of animal products [2], as does the level of income of household heads. Regarding the use of animal species depending on opportunities, it is consistent with observations made in Burkina Faso [12] and in Sénégal [15]. Indeed, sheep, goats and cattle are sacrificed for ceremonies and events gathering a large number of people while chickens are widely sought to honor guests and friends to strengthen social bonds. During the Ramadan festival period and the New Year, the meat of small ruminants is sought more than chicken meat; unlike some countries such as Sénégal where chicken meat is much sought during these periods [27]. In Chad, sharing meals with family and friends during these celebrations requires a somewhat larger amount of meat, hence the use of small ruminants.

Frequency of consumption is influenced by household income and size. The low-income households do not allow a high frequency of chicken consumption, unlike the middleincome households with fewer dependents. Our frequency of indigenous chicken consumption was lower than those "out homes" in the same city that vary over time; daily (3\%), weekly (51\%); twice per week (23\%); three times a week (5\%) and monthly (18\%) [11]. The continuous working days and the multiplication of grilling points and street restaurants would explain these high frequencies. The average consumption level per person surveyed was similar to the results obtained in the same city [17]. The annual extrapolations on the basis of average daily sales in the markets and on the total poultry traders indicate an average consumption of $1.80 \mathrm{~kg} / \mathrm{ht} /$ year in N'Djamena. Note that the data on the average consumption bearing exclusively on indigenous chickens in sub-Saharan African countries are not so much available. In households in N'Djamena, the indigenous chicken is mainly used in cooking stews or sauces and soup. In Dakar in Sénégal [27], the main dishes prepared using indigenous chicken are rice dishes (53.2\%), sauces $(19.3 \%)$, fried chicken $(11.1 \%)$ and served with some couscous (16.4\%). The differences would be put on the account of eating habits. In Sénégal, a variety of chicken dishes is observed.

The main determining factor for choosing the indigenous chicken is the price, due to the fact that the chicken is expensive given the purchasing power of different households [4]. Notwithstanding the survey periods, we see that in N'Djamena, the average price of chicken was higher than that in Niger [3], in Bangui (Central African Republic), in Cotonou (Bénin), in Bamako [10], in Yaoundé [4, 13] and Dakar [27]. At the time of the investigation under consideration, the price of chicken at the market was higher than the national average price of $1,840 \mathrm{~F}$ CFA in 2008 [17] and the price recorded during the "out homes "consumer study in 2010 which was 2,160 FCFA [11]. The high cost of indigenous chickens in N'Djamena compared to prices in 2010 and to those in other African cities could be explained by the fact that the studies were conducted in the months of November and December, which corresponds to the period of Christmas and New Year celebrations. Moreover, unlike other African countries, there are very few semi-industrial broiler rearing and egg-laying chicken farms (for reform hens) in Chad. Similar results are obtained in Ethiopia [2] showing that poultry prices are higher during periods of peak sales such as Christmas and New Year (December-January) and Easter (April) and they fall in periods of fasting and Easter (February) which coincide with low sales. Price fluctuations during certain periods of the year are also recognized in the markets of Kampala in Uganda [5]. Besides the price, the weight and age of the chicken are also considered to be criteria that influence the consumers' choice at the time of purchase. Observations made in Ethiopia indicate that Ethiopian consumers preferred young chickens compared to old chickens [2].

The organoleptic quality attributes that led to the consumption of indigenous chicken in N'Djamena compared to other meats in households, were similar to those obtained in Tanzania [16] where local chickens are preferred by consumers because of their pigmentation, the thinness, their taste and the ability to cook special dishes. As for the motivations and factors determining the preference of indigenous chicken in households, our results agree with those obtained in Zimbabwe [20], Ethiopia [2], Sénégal [27] and Uganda [5]. These authors believe that the organoleptic characteristics, including taste and nutritional aspects, are the main characters that drive the consumption of indigenous chicken in households. Consumers in the city of Dakar (Sénégal) believe that the hen, particularly that in time of egg-laying, has a much tastier flesh [27].

Traditionally, poultry is used in mystical practices. Thus, in some local communities, chickens or their products can ward off evil spells targeting the family or a family member [9]. The chicken used in mystical-social practices should meet criteria that differ from the chicken intended for common consumption [27]. In our case, color (66.7\%) and gender $(32.2 \%)$ are the main criteria for the choice of chickens intended for sacrifice. These results are similar to those obtained by some authors [22, 27]. According to these authors, the color of feathers and sex of the chicken can direct its destiny either for sacrifice, or to be used to welcome a guest or to as an offering. As for the mode of the mysticalsocial use of the local chicken, our results showed that in the majority of cases, the chicken is bled $(48.6 \%)$, cooked and distributed $(35.2 \%)$ or given to the marabout. In Sénégal, however, the indigenous chicken can be given alive to a stranger [27]. But in Ethiopia, a rooster with red and white plumage is sacrificed for good rain and harvest, that which has red feathers with black spots is sacrificed to celebrate the New Year, a white and black rooster is sacrificed to prevent evil and disasters, and that with red pullets is sacrificed to the dead ancestors [24]. 


\section{Conclusion}

This study made it possible to determine the socioeconomic characteristics of household heads, purchasing and consumption practices of indigenous chickens in the households in the city of N'Djamena. The same was done concerning expenditure on food consumption, which remains based on household size and income. In N'Djamena, indigenous chicken is the main poultry meat consumed in households in the form of sauce and soup. In addition, they are widely sought at various festive and ritual ceremonies. Thus, traditional poultry farming plays a major role in favoring animal protein intake and meeting the urban population demand in poultry meat. Price remains the main criterion for choosing the chicken at the time of purchase. The low semi-industrial poultry production highlights the indigenous one to meet chicken meat needs of city dwellers. For the development of traditional poultry farming in Chad and in order to better meet the increasingly growing needs of consumers, it is important to implement a policy of sustainable development of this sector.

\section{References}

[1] Agbede G.B., Teguia A. et Manjeli Y., 1995. Enquête sur l'élevage traditionnel des volailles au Cameroun. Tropicultura, $13,(1): 22-24$

[2] Aklilu H.A., Almekinders C.J.M, Udo H.M.J., Van Der zijpp A. J., 2007. Village poultry consumption and marketing in relation to gender, religious festivals and market access. Tropical Animal Health and Production. 39:165-177

[3] Assoumane I., Ousseini G., 2010. Revue du secteur avicole du Niger. http://www.fao.org/docup/012/ak770f/ak770f00.pdf. 61 p. (05 Août 2010)

[4] Awono Bessa C., Laroche-Dupraz C., Grongnet J. F., Vermersch D., Havard M., Lhuissier A., 2008. Déterminants de la consommation urbaine de poulet de chair au Cameroun: cas de la ville de Yaoundé. In : Parrot L., Njoya A., Temple L., Assogba-Komlan F., Kahane R., Ba Diao M., Havard M. (éds scientifiques), Parrot L. (coordonnateur), Tome 1 : Gouvernance et approvisionnement des villes, Editions L'Harmattan. 209-218

[5] Emuron N., Magala H., Kyazze F.B., Kugonza D.R., Kyarisiima C.C., 2010. Factors influencing the trade of local chickens in Kampala city markets. Livestock Research for Rural Development, 22 (4), Art. \#76. Retrieved May 7, 2011, from http:// www.Irrd.org/Irrd22/4/emur22097.htm

[6] Faye B., Alary V., 2001. Les enjeux des productions animales dans les pays du Sud. Prod. Anim., 14, 3-13.

[7] Guérin H., Faye B., 1999. Spécificité de la problématique périurbaine pour les systèmes d'élevage. In : P. Moustier, A Mbaye, H. De Bon, H. Guerin, J. Pages (éds scientifiques), Actes de l'atelier «Agriculture périurbaine en Afrique subsaharienne ». Cirad-Coraf, 20 - 24 avril 1998, Montpellier, France, p. $43-49$

[8] Guèye E. F., 2000. The role of family poultry in poverty alleviation, food security and the promotion of gender equality in rural Africa Outlook on Agriculture, 29, 129-136.
[9] Guèye E.F., 2005. Le rôle de la volaille villageoise et des petits ruminants pour la réduction de la pauvreté et la facilitation de la sécurité alimentaire. Rapport de l'atelier mouvements. Du 7 au 8 novembre 2005 Ouagadougou (Burkina Faso).

[10] Horman D., 2004. Le poulet Africain étouffé par l'Europe. http://www.gresea.be. 136p. (25 Octobre 2010)

[11] Issa Y., Mopate L.Y., Louassouabe G., Ayssiwede S.B., Missohou A., 2012. Consommation hors-foyer de poulets traditionnels dans la ville de N'Djaména (Tchad). Revue Scientifique du Tchad Janvier - 2012. Volume 11 - Numéro Spécial 1 (42-52)

[12] Kondombo S.R., Nianogo A.J., Kwakkel R.P., Udo H.M.J., Slingerland M., 2003. Comparative analysis of village chicken production in two farming systems in Burkina Faso. Tropical of Animal Health and Production, 35:563-574.

[13] Laroche Dupraz C, Awono Bessa C., Vermersch D., 2008. Application de la théorie de Lancaster à la consommation de poulet de chair au Cameroun. Revue d'Etudes en Agriculture et Environnement.

http://www.raestud.eu/pdf/079 98_laroche.fin.pdf.79-98 p. (05 Août 2010)

[14] Ministère de l'Economie et du Plan (MEP)., 2009. Institut National de la Statistique, des Etudes Economiques et Démographiques (INSEED). Rapport provisoire du 2ème Recensement Général de la Population et de l'Habitat (RGPH2) du Tchad. 88 p.

[15] Missohou A., Dieye P.N., Talaki E., 2002. Rural poultry production and productivity in Southern Sénégal. Livestock Research for Rural Development, 14 (2) http://www.cipav.org.co/lrrd//rrd14/2/miss142.htm

[16] Mlozi M. R. S., Kakengi A. V. M., Minga U. M., Mtambo A. M., Olsen J. E., 2003. Marketing of free range local chickens in Morogoro and Kilosa urban markets, Tanzania; Livestock Research for Rural Development, 15 (2). Retrieved June 12, 115, from http://www.lrrd.org/lrrd15/2/mloz152.htm

[17] Mopaté L.Y., 2010. La filière volaille locale dans l'approvisionnement en viande des villes : cas de la ville de N'Djaména au Tchad. Atelier pour le Développement de l'Aviculture Professionnelle au Tchad (DAPT), du 09 au 12 juin 2009, à N'Djaména (Tchad). Ministère de l'Elevage et des Ressources Animales (MERA), International Finance Corporation (IFC) of the World Bank Group, FAO, SCAC (Ambassade de France), LRVZ, p. 14-18.

[18] Mopaté L. Y., Awa N. D., 2010. Systèmes avicoles en zone de savanes d'Afrique centrale : performances zootechniques et importance socio-économique. L. SEINY-BOUKAR, P. BOUMARD (éditeurs scientifiques), 2010. Actes du colloque International, avec comité de lecture, intitulé «Savanes africaines en développement : innover pour durer», 20-23 avril 2009, Garoua, Cameroun. PRASAC, N'Djaména, Tchad ; CIRAD, Montpellier, France, Version 1 mise en ligne sur http://hal.cirad.fr/cirad-00472067/fr/, ou Version 2 sans modification sur $\mathrm{CD}, 11 \mathrm{p}$.

[19] Moustier P., 1999. Définitions et contraintes de l'agriculture périurbaine en Afrique subsaharienne. In : P. Moustier, A Mbaye, H. De Bon, H. Guerin, J. Pages (éds scientifiques), Actes de l'atelier " Agriculture périurbaine en Afrique subsaharienne ». Cirad-Coraf, 20 - 24 avril 1998, Montpellier, France, p. $29-42$ 
[20] Muchadeyi F C, Sibanda S, Kusina N T, Kusina J., Makuza S., 2004. The village chicken production system in Rushinga District of Zimbabwe. Livestock Research for Rural Development, 16 (6), Art. \#40. Retrieved July 20, 2011, from http://www.lrrd.org/lrrd16/6/much16040.htm

[21] Salomon A., Workalemahu A., Jabbar M., Ahmed M., Hurnissa B., 2003. Livestock marketing in Ethiopia. A review of structure, performance and development initiatives, (Socioeconomic and Policy Research Working Paper 52; International Livestock Research Institute, Nairobi, Kenya).

[22] Savane M., 1996. L'aviculture rurale au Sénégal, contraintes et perspectives zoo-économiques : Cas de la haute Casamance. Thèse Méd. Vét., EISMV, $N^{\circ}$ 9, Dakar

[23] SPSS, 2009. Statistical Package for Social Sciences. Version 17.0, SPSS Incorporated, Illinois, USA.

[24] Tadelle D., Olge B., 2001. Village poultry production systems in the central highlands of Ethiopia. Tropical Animal Health and Production, 33:521-537
[25] Talaki E., 2000. Aviculture traditionnelle dans la région de Kolda (Sénégal). Thèse : Méd. Vét. EISMV, N 10, Dakar

[26] Temple L. et Moustier P., 2004. Les fonctions et contraintes de l'agriculture périurbaine de quelques villes africaines (Yaoundé, Cotonou, Dakar). Cahiers Agricultures, 13 (1) : 15 $-22$

[27] Teno G., 2009. Etude des déterminants de la consommation du poulet du pays: cas de la région de Dakar (Sénégal). Thèse Méd. Vét., EISMV, $\mathrm{N}^{\circ} 36$, Dakar

[28] Traoré M., 2005. Evaluation de l'impact d'un transfert de paquet technique (amélioration génétique et des conditions d'élevage) sur la génération de revenus en aviculture traditionnelle dans les Niayes. Thèse Méd. Vét. EISMV, $\mathrm{N}^{\circ} 23$, Dakar

[29] Traoré E. H., 2006. Première évaluation de la structure et de l'importance du secteur avicole commercial et familial en Afrique de l'Ouest. Rome: FAO. 52 p.

${ }^{\mathrm{i}} 1 \mathrm{USD}=500 \mathrm{~F} \mathrm{CFA}$ 